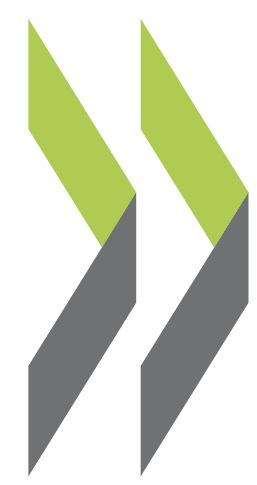

OECD Local Economic and Employment Development (LEED) Papers 2014/01

\title{
Women's Social Entrepreneurship and Innovation
} Marieke Huysentruyt 


\section{WOMEN'S SOCIAL ENTREPRENEURSHIP AND INNOVATION}

Marieke Huysentruyt,

the SELUSI Project - Belgium 
OECD Working Papers should not be reported as representing the official views of the OECD or of its member countries. The opinions expressed and arguments employed are those of the authors.

Working Papers describe preliminary results or research in progress by the author(s) and are published to stimulate discussion on a broad range of issues on which the OECD works. Comments on Working Papers are welcomed, and may be sent to Antonella Noya (Senior Policy Analyst), OECD, 2 rue André-Pascal, 75775 Paris Cedex 16, France.

Authorised for publication by Sergio Arzeni, Director, Centre for Entrepreneurship, SMEs, Tourism and Local Development

The statistical data for Israel are supplied by and under the responsibility of the relevant Israeli authorities. The use of such data by the OECD is without prejudice to the status of the Golan Heights, East Jerusalem and Israeli settlements in the West Bank under the terms of international law. 


\section{TABLE OF CONTENTS}

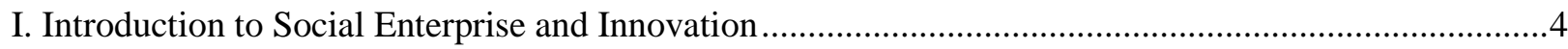

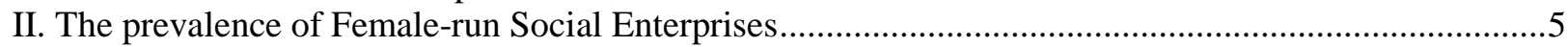

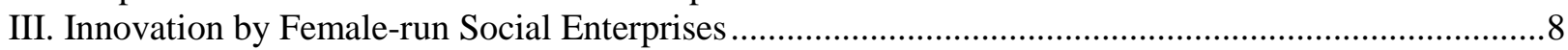

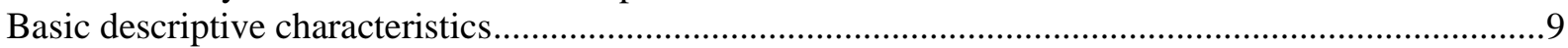

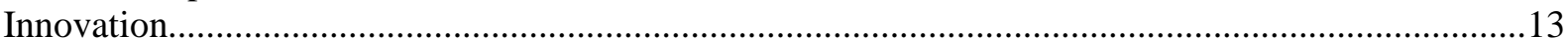

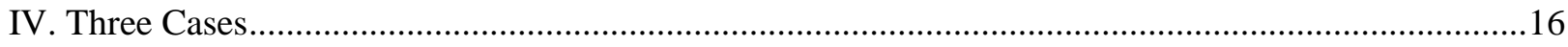

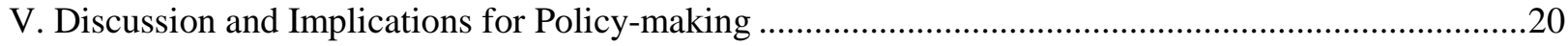

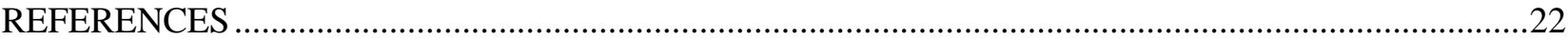

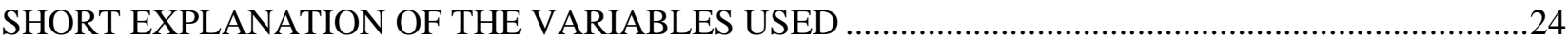

\section{Tables}

Table 1. Female directors and social enterprise revenue ..............................................................12

Table 2. $\quad$ Female directors and Participatory Management Practices...................................................13

\section{Figures}

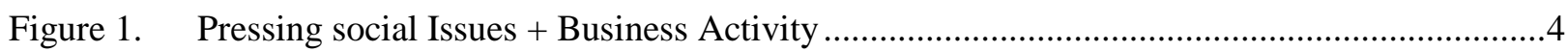

Figure 2. Social Entrepreneurs are more radical innovators ..........................................................

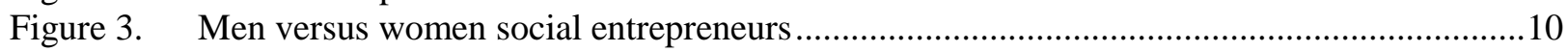

Figure 4. Social enterprises led by men versus women ................................................................11

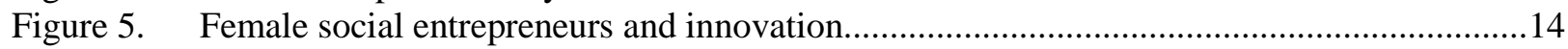

\section{Boxes}

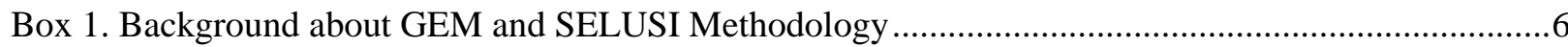

Box 2. Why sex differences in basic values and attitudes towards competition? ......................................8

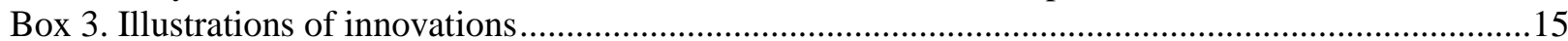




\section{Introduction to Social Enterprise and Innovation}

A remarkable mind-shift seems today well underway: major social issues and challenges, be it in the area of sustainability and the environment or poverty and societal cohesion, are no longer perceived as restraints on growth and firm behaviors, but rather as opportunities, driving a new wave of growth and innovation. In other words, there is a new opportunity space for growth and innovation rapidly unfolding precisely at the intersection between societal trends and business activity. Socially responsible businesses and social enterprises are at the edge in this space - spearheading initiatives which aim to achieve a large, positive societal impact and at the same time are also economically viable or sustainable (see Figure 1).

Figure 1. Pressing social Issues + Business Activity

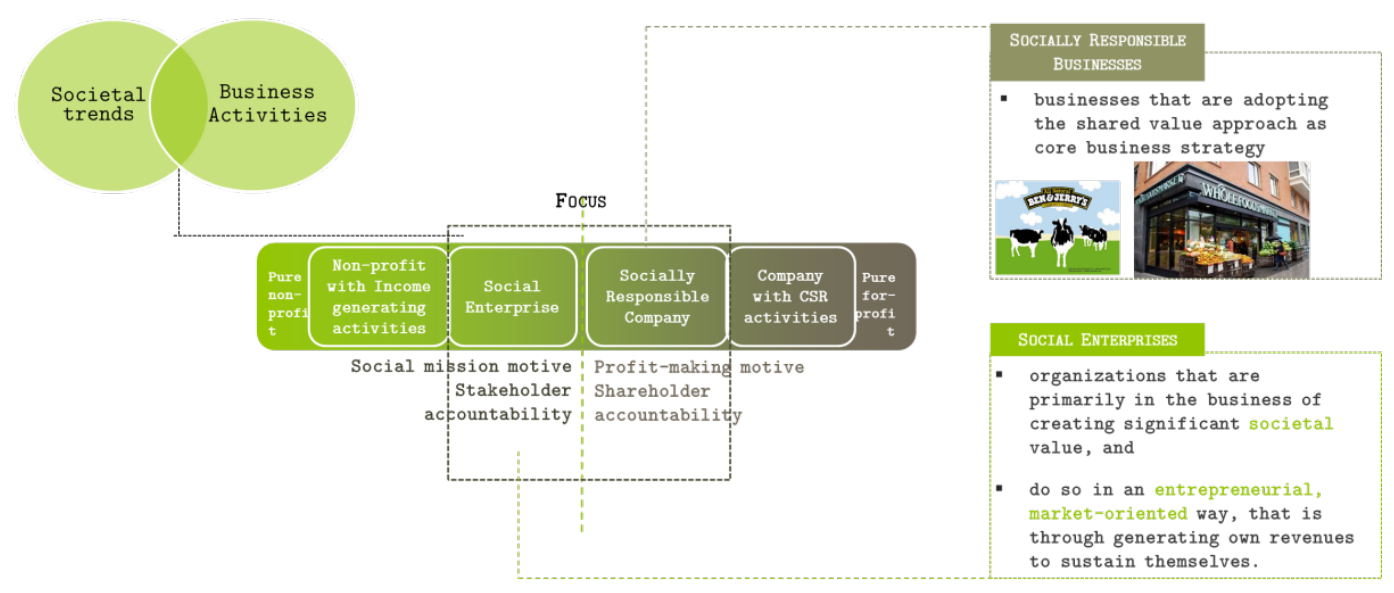

The focus of the present report is on social enterprise, admittedly a niche type of enterprise, but with arguably enormous (underexploited) potential to help lead society to evolve a genuine, caring "shared value" economy - a society where societal and economic progress are (again) much more tightly, boldly and positively linked together. The latter conjecture draws on three key empirical findings.

1. Social enterprises have been found to pursue activities in many different sectors ranging from construction and energy over education, health and social work to retail and community services, often with a special focus on services. Their wide reach in services is of special global relevance given that the services sector accounted for almost 71\% of global GDP in 2010 and is expanding at a quicker rate than the agriculture and the manufacturing sectors. The nature of the social good they produce is also very diverse. Some aim to widen access to services, like education, health, financial and legal services. Others aim to trigger positive behavioral change, like recycling or healthy behaviors. Others still aim to redress market failures - like climate change. Interestingly, many configure their operations such that tackle more than one societal challenge simultaneously. For instance, fighting food waste or promoting the reuse of materials, and at the same time employing disadvantaged or marginalized people who struggle to find a job.

2. Social enterprises have been found to be more sensitive - and responsive - to social market needs. They systematically identify and respond to such needs long before the bulk of the marketplace encounters them. In this sense social enterprises are on the cutting edge when it comes to dealing with certain needs, and that obliges them to innovate as a matter of course. 
3. Social enterprises have also been found to outperform comparable mainstream businesses or public sector bodies when it comes to launching radical innovations (see Figure 2), 65\% of which have a significant service component. Social enterprises are also opening up new markets at a much higher rate than mainstream entrepreneurial start-ups do.

Figure 2. Social Entrepreneurs are more radical innovators

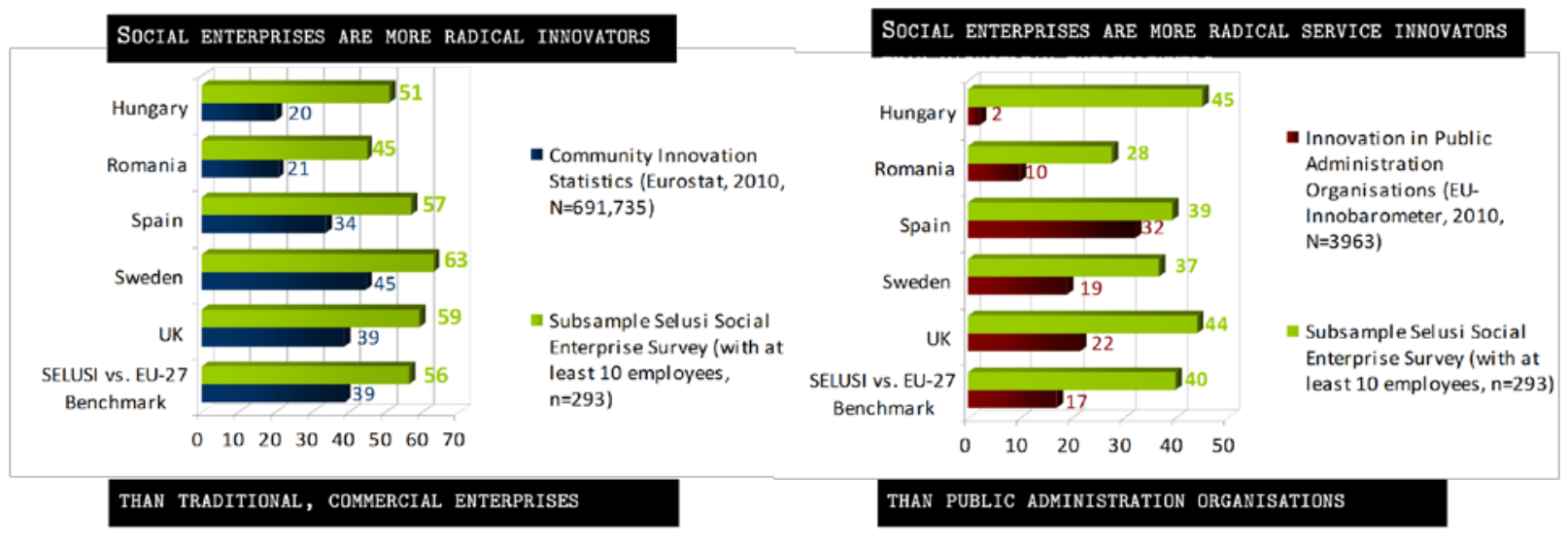

Having said this, we must be mindful of the fact that social enterprise today is still a niche phenomenon in statistical terms. To illustrate, worldwide, on average $2.8 \%$ of people aged $18-64$ are involved in social entrepreneurial activity as a nascent entrepreneur (thinking to start-up a social enterprise) or manager-owner of a new business (running a social venture that is less than 3.5 years old) (GEM, 2009). Considering this and the sheer scale and rapid proliferation of major societal problems, we mustn't assume that social enterprise alone can redress all injustices, inequalities, etc. Rather, it is important that we -businesses, civil society, academics and government agencies alike- find ways to effectively leverage and complement the specific intelligence and experiences that social enterprises hold, and consequently drastically accelerate the speed to society and rates of diffusion of workable, new solutions to our most complex social problems.

In this report, we zoom in on women social entrepreneurs: who are the they, what is distinct about them, and are they specially innovative, and if yes, in which way? We hereby aim to nuance the on-going debates about social entrepreneurship, bringing to bear original, rich and reliable new evidence on especially women social entrepreneurs who typically are not in the spotlight. We also aim to bust more than one "myth" - that is, popular ideas and their assumptions- about women social entrepreneurship and innovation, and rather place our understanding of women social entrepreneurship on a more solid knowledge base. We aim to whet your appetite to find out more, think critically and help create space for more radical thinking about the future of women-led social innovation and entrepreneurship worldwide.

\section{The prevalence of Female-run Social Enterprises}

Despite intensifying policy interests, few systematic, reliable data on social enterprises currently exist. The main reason is that social enterprises essentially constitute what sociologists refer to as a 'hidden population'. They not only represent a niche type of entrepreneurial activity, but also their identity cannot be readily retrieved from telephone directories or administrative databases. Additionally, a sample based on individual self-identification with the term 'social enterprise' is prone to large biases because a common, shared knowledge of and widespread familiarity with social enterprise are still in most country contexts outright lacking. 
In the remainder we draw on evidence generated by two recent large-scale, cross-country survey programs on social entrepreneurship, which are methodologically sound (see Box 1): the Global Entrepreneurship Monitor (henceforth, GEM) and the LSE-SELUSI Database (henceforth, SELUSI). Interestingly, both bodies of survey evidence suggest that the gender gap in social entrepreneurship is generally smaller than the gender gap in traditional, commercial entrepreneurship.

\section{Box 1. Background about GEM and SELUSI Methodology}

The Global Entrepreneurship Monitor collates comparable data across a large variety of countries on attitudes toward entrepreneurship, start-up and established business activities, and aspirations of entrepreneurs for their businesses. One of GEM's principal indicators reflects total early-stage entrepreneurial activity, mentioned earlier, based on interviews with population representative samples of 18-64 year-olds in over 54 countries worldwide. In 2009, GEM additionally assessed the prevalence of early-stage social entrepreneurial activity (SEA), which they define as involvement in (i) trying to start-up or (ii) managing and owning any sort of activity, organization that has a particularly social, environmental or community objective. While SEA is thus very broad, the GEM leading researchers have also taken steps at trying to parcel out say traditional nonprofits. The SEA figures are based on interviews with a population representative sample of 150,000 individuals in 49 countries worldwide.

The LSE-SELUSI database captures detailed market- and organization level information on over 550 social enterprises in Hungary, Romania, Spain, Sweden and the UK. The database is a panel database. Focus is on ventures driven by a social mission, that self-generate at least $5 \%$ of own revenues and employ at least 1 FTE. The data is collected using a respondent-driven sampling (RDS) technique: a chain-referral procedure that exploits respondents' social networks. By combining the breadth of coverage of network-based sampling methods with the statistical validity of standard probability sampling methods, RDS enables them to provide both unbiased population estimates and measures of the precision of those estimates. GEM focuses particularly on the enterprise start-up phase and does so cross-sectionally, while the LSE-SELUSI database provides greater in-depth and longitudinal information on multiple phases of venture development.

The GEM data (2009) show that males are generally more likely to start a social venture than females, but in comparison with traditional, commercial entrepreneurial activity females are relatively more prevalent in social entrepreneurial activity. The portion of women to men in SEA ( $\mathrm{Pf} / \mathrm{Pm}=0.68$ ) is higher than the proportion of women to men in TEA $(\mathrm{Pf} / \mathrm{Pm}=0.58)(\mathrm{z}=-3.76, \mathrm{p}<.0001)$. The difference in proportions of TEA and SEA for women is $10 \%$ with a $5.3 \%$ margin of error.

The female-male SEA ratios notably vary tremendously across country contexts. In some countries, like Argentina, Iceland, Israel, Lebanon, and Russia, women social entrepreneurs outnumber their male counterparts, while in others, most prominently so in Brazil, Bosnia Morocco, the opposite holds true. In yet other countries, like China, Finland, Latvia, and the US, the proportion of males and females in SEA is roughly the same (Terjesen et al., 2011).

The 2010 SELUSI data corroborate this result. Males are generally more likely to be leading the social enterprise than females, yet considerable country differences exist. They show that in Hungary and Romania, the ratio of female to male-run social enterprises is over 1 (1.86 and 1.27 , respectively) meaning there is a relative predominance of female-run over male-run social ventures, whereas below 1 in Spain and the UK (0.32 and 0.67 , respectively). In Sweden, social ventures are more or less equally likely to be run by men versus women.

Furthermore, this 'smaller gender gap in social entrepreneurship'-result in social entrepreneurship also resonates well with findings drawn from other sources of evidence. For instance, we know that women's participation rate in the non-profit sector (including paid employment) is higher than men's (Themudo, 2009). And even as commercial entrepreneurs, women seem to emphasize social goals more, and economic goals less (when pursuing entrepreneurial activity) relative their male counterparts. Of 
course, this doesn't prove that women commercial entrepreneurs also achieve more social goals, but it suggests that at a minimum differences in "discourse” (stated goals) exist (Hechavarria et al., 2012).

How can we explain the apparent smaller gender differences in social entrepreneurship relative to commercial entrepreneurship? We offer two strands of explanations;

1. women are generally more altruistic and socially minded than men, and because of this motivation -caring directly about the social payoff-, they are more likely to found or manage a social enterprise than a pure for-profit form. Computerized experiments have been used to study gender differences in social preferences: in particular, public good experiments, ultimatum experiments and dictator experiments. The difficulty in interpreting and comparing results of many of these experiments, however, arises from differences in design: some include financial risk, while others do not. ${ }^{1}$ Some designs expose the subjects and their decisions to the decisions of others, while others do not. ${ }^{2}$ Women seem to be more sensitive to cues in the experimental context than men (Croson and Gneezy, 2009). Eckel and Grossman (2008) argue that the experimental evidence in favor of women being more socially oriented is much stronger if one restricts oneself to those experimental designs where researchers have managed to abstract away from risk and have provided more anonymity to the subjects. In this regard, the evidence on dictator experiments is typically subject to less confounding factors. Overall, the dictator experiments find evidence that is broadly consistent with women giving away more than men. There is also quite a lot of field evidence consistent with a higher level of altruism and stronger preference for redistribution among women. Some of this evidence is indirect, coming from observed gender differences in political orientation. Other papers provide more direct evidence on the geder gap in policy preferences (Chattopadhyay and Duflo, 2004). Additionally, a large, robust literature on individual values reveals that women attribute consistently more importance than men do to benevolence and universalism values (self-transcendence); the reverse is true for power, stimulation, hedonism, achievement, and self-direction values. The sexes do not differ on tradition and conformity values. However, these gender differences are small (median $d=0.15$; maximum $\mathrm{d}=0.32$ [power]) and typically explain less variance than age and much less than culture (Schwartz and Rubel, 2005). ${ }^{3}$ (see also Box 2 for more explanation).

2. women are more averse to competition, and because the markets of social enterprises are generally newer, less mature and less dominated by competitive pressures than the markets of commercial entrepreneurship, women are more likely to found or manage a social enterprise than a pure for-profit form. Women are more reluctant than men to engage in competitive environments, like tournaments, bargaining and auctions (see Box 2 for more explanation). We also know from analyses of SELUSI data that social entrepreneurs place significantly lower emphasis on 'competitive aggressiveness' than commercial entrepreneurs. In fact, contrary to mainstream entrepreneurs, competitive aggressiveness is not even part of the entrepreneurial posture of social entrepreneurs (SELUSI 2010 data; see Covin and Slevin, 1989; Lumpkin and Dess, 1996 on the construct of strategic orientation towards entrepreneurship). But of course, this could be because of the gender gap differences revealed earlier. However, this could also be explained by the newness of the markets social enterprises typically operate in, which stimulates them to be more to collaboration, which is exactly what we also find empirically. They generally

This is problematic since we know there are systematic gender differences in risk aversion (Bertrand, 2010).

2 Yet women and men may care differentially about how others judge their behavior.

These figures summarize findings from 127 samples in 70 countries $(N=77,528)$, whereby values are measured using validated survey instruments. 
first cooperate to increase the pie (create and build up the market), only thereafter do they really compete. This is a great illustration of the term 'co-opetition' - coined by Brandenburger and Nalebuff (1996). However, this also alerts us to the possibility that the gender gap in social entrepreneurship might increase when in those markets competitive pressures intensify. In fact, the mature market of micro-finance institutions may well be showing signs of the like: it has been argued that a glass ceiling exists in the microfinance sector amid rapid commercialization and women managers in microfinance institutions need to face up to the challenges of a competitive environment (Segram, 2010).

\section{Box 2. Why sex differences in basic values and attitudes towards competition?}

Evolutionary theorists interpret these sex differences as reflecting different adaptation problems regularly faced by our male and female ancestors (e.g., Geary, 1998; Pinker, 2002). Presumably, the long history of differential evolutionary pressures on men and women has led to the development of cognitive and affective mechanisms that differentiate the sexes. Values, as guides to behavior, may be viewed as one such mechanism. In contrast to evolutionary psychology's focus on humankind's past adaptations, social role theory locates the source of sex differences in the current or recent division of labor (Eagly, Wood, and Diekman, 2000). Occupational and family roles and the allocation of women and men to them provide sex-differentiated experiences that directly influence behavior, identities, attitudes, and basic values. Moreover, the different common role occupancies of the sexes produce diffuse gender role expectations that indirectly influence men and women, regardless of their placement in specific occupational and family roles (Eagly, Beall, and Sternberg, 2004). Thus, sex-typed role experiences and gender role expectations can both explain sex differences in basic values.

As with gender differences in altruism and pro-social values, one important question about these gender differences in attitudes toward competition is whether they are ingrained (nature) or taught (nurture). Under the nature explanation, at some point in history women and men evolved different strategies to maximize the fitness of their genes. For example, genetic or hormonal differences could lead women to be less competitive than men. Support for this explanation can be found in studies of the effect of biological measurements on behavior. Under the nurture explanation, societal structure is crucially linked to gender differences in competitiveness. For example, the fact that gender differences exhibit only later in life suggests an environmental cause. In sum, there is evidence in favor of both explanations. Going forward, the research question is likely to be the relative weights of these two factors and there interaction.

In sum, gender differences in social preferences and attitudes toward competition are consistent with the apparent smaller gender divide in social entrepreneurship than commercial entrepreneurship. Further research is needed to reliably establish the relative importance of and interrelationship between these factors. Knowing this would help policy-makers better understand under which conditions policies directed at promoting social entrepreneurship specifically can have a direct, differential impact on men versus women.

\section{Innovation by Female-run Social Enterprises}

Little is known about whether women run their social ventures systematically differently than their male counterparts, let alone particularly in the area of innovation. Do they display distinct management styles when it comes to innovation compared to their male social entrepreneurs? This is in fact a far more difficult question to address empirically than one might intuitively suspect. The difficulty is to prove causality.

We will thus first investigate (i) the extent to which men and women social entrepreneurs differ in terms of observable background characteristic, and (ii) the extent to which women and men self-select into distinct types of social ventures. Because if the women and men that choose to run social ventures say were to differ in educational background, then it would be difficult to disentangle the influence of education on a 
venture's innovation performance from that of 'being a woman'. Likewise, if the sector or business activity of the ventures run by male versus female social entrepreneurs systematically differ, then this will hamper our ability to attribute any gender differences in innovation styles to female-male differences, rather than differences in the types of businesses they run (and the corresponding best fitted management practices). To take steps at ruling out possible confounds, we thus begin with a comparison of observable individualand social venture-level characteristics. Next, we narrow our focus to the topic of special interest, namely innovation.

All of the data we bring to bear onto these questions are SELUSI data as these are, to the best of my knowledge, the only data that include detailed information about the social enterprise, the director's management style and background characteristics, and the organization's innovation activity. It must be noted that these data provide insights on 5 European countries only, so one needs to be cautious about trying to extrapolate to other contexts.

\section{Basic descriptive characteristics}

\section{Background characteristics of the social entrepreneur}

In terms of standard background characteristics, male and female social entrepreneurs look very much alike. We observe no significant difference in educational background between men and women running a social enterprise. Both female and male social entrepreneurs tend to be highly educated, having completed on average a Master's degree. The propensity to engage in social entrepreneurship thus seems to be related to education, a point which can be gleaned from GEM data on SEA in 52 countries worldwide as well. Despite the fact that a minority of population in these countries have completed post-secondary and graduate education, these are the people most likely to be running a social enterprise.

Women social entrepreneurs seem to be slightly younger than their male counterparts (45.2 versus 46.9 years old for men). The highest proportion (35\%) of social enterprise directors overall is aged between 35 and 44; this was followed by the age group 45-54 (30\%). This holds true for both female and male directors. Only in the age group of over 55 year olds (55+) do female directors appear to be significantly underrepresented (18\% versus $26 \%$ of men) (Figure 3 ). 
Figure 3. Men versus women social entrepreneurs

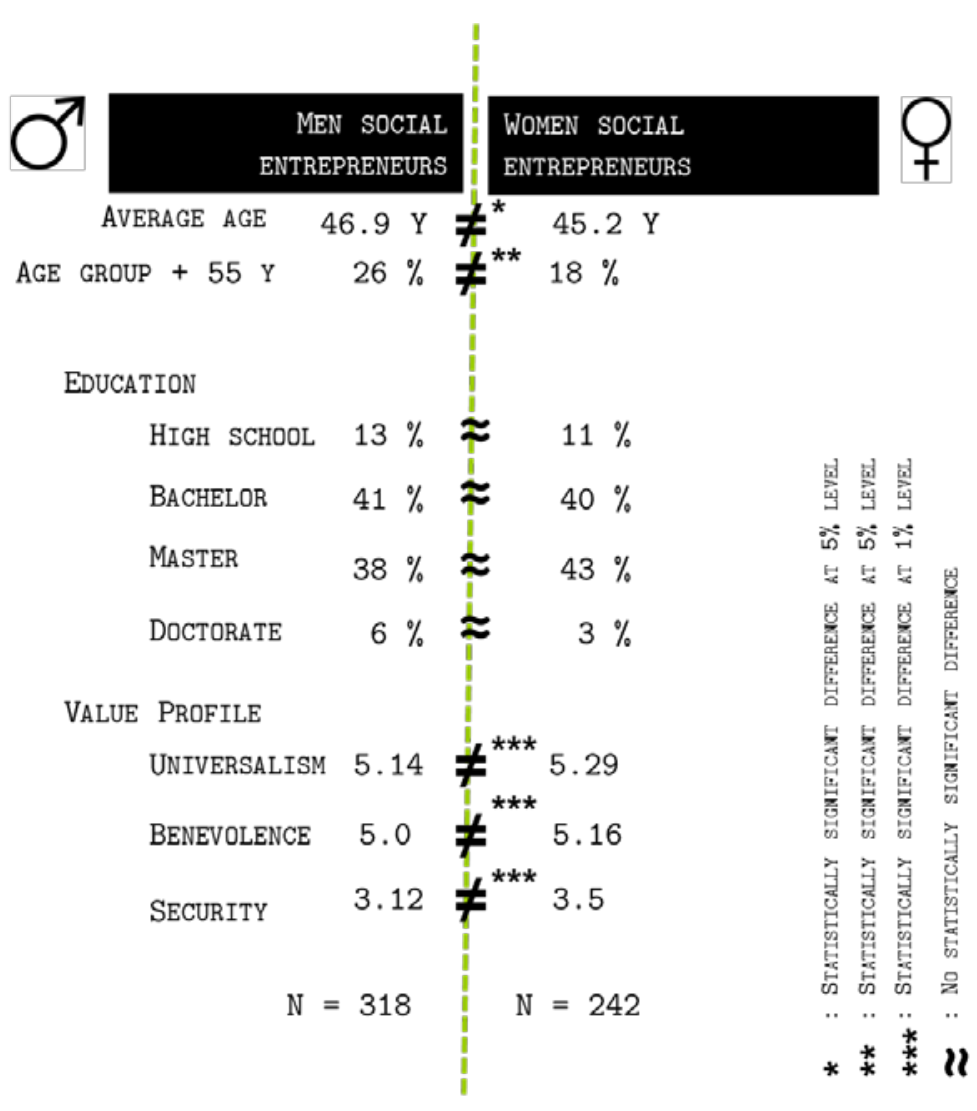

\section{Characteristics of the social enterprise}

The average age of the ventures run by women is also marginally below that of male run ventures (13 versus 16 years old). This difference is in effect driven by the gender difference in age of the social enterprise amongst the oldest ventures - those that were founded at least 20 years ago. Within this organizational age group (of size $\mathrm{N}=114$ ) we observe a significantly higher proportion of men at the helm: $70 \%$ of the social enterprises over 20 years old are male run.

Women-led social enterprises are relatively more prevalent in the domains of social services (32\% of female run ventures versus $18 \%$ of male run ventures) and health (15\% versus $8 \%$ ). For all the other social sector types (which include, listed in the order of frequency, e.g. development and housing, education and research environment, and culture and recreation), no gender differences were found. ${ }^{4}$ Additionally, in terms of the ventures' industry types (NACE Classification), we observe that social enterprises led by women are less likely to be active in the area of business services (like financial intermediation, consulting,

Overall, the highest proportion of social ventures were active in the areas of development and housing (18\%), social services (16\%), education and research (15\%), and the environment (14\%). Interesting country-differences, however, exist. For instance, in Romania, half of all ventures operate in the area of social service delivery (NPO category: 4 100); in Spain the biggest proportion of social ventures (43\%) was found in the area of employment and training (NPO category: 6 300). 
etc.) $-20 \%$ versus $28 \%$ of male run ventures- and more so in the area of health and social work $-28 \%$ versus $12 \%$ of male run ventures. ${ }^{5}$ (Figure 4 )

Figure 4. Social enterprises led by men versus women

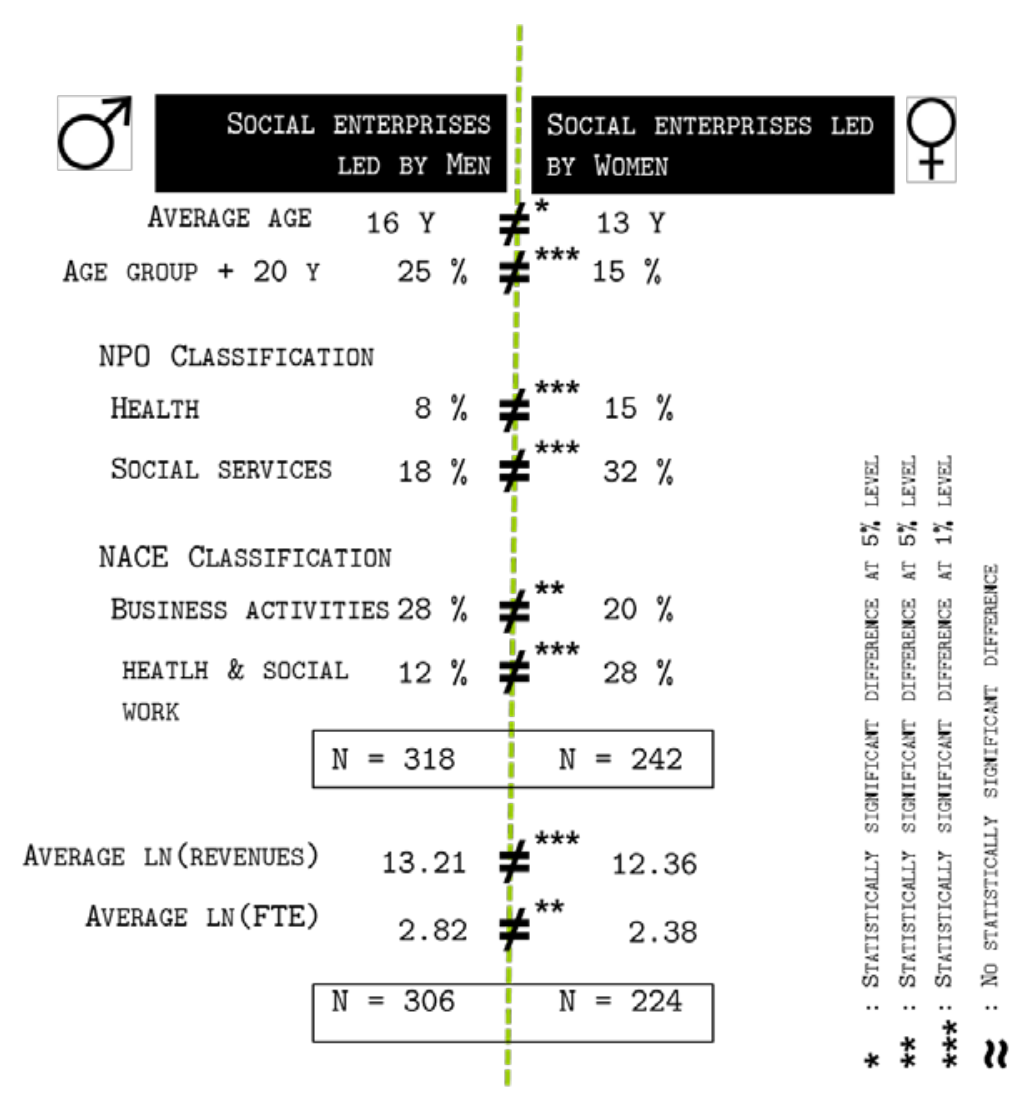

It seems as if the ventures run by women are systematically smaller, both in terms of total revenues generated (log of revenues in the past year in EUR) and number of full-time equivalents employed (log of FTE), compared to those run by men. However, once we move beyond simple comparisons of means across gender groups, the picture becomes a bit more nuanced. In fact, when we control for the director's age and level of education, organization's age; organization's sector or industry type, operational model, and include country fixed effects and interaction terms country fixed effects and gender, the main effect of gender disappears (Table 1). In those regression analyses where we so try to explain between-firm variation in the log of revenues, we find no overall main effect of gender. However, there seems to be a gender difference in log of revenues in Hungary and the UK. A similar picture emerges when we regress the log of FTE on director and organization-specific characteristics. Additionally, we find no clear evidence that women have a preference to stay 'small' when we compare men and women-led ventures in a same social sector domain. These results clearly beg further research. But they highlight the significance of culture and country contexts, cast some doubts on the veracity that women don't go after 'big', 'successful' and 'large', but rather tend to 'think smaller' (see INSEAD Knowledge).

$5 \quad$ It must be noted that all of these classifications consider the first three mentioned (main) activity of the social venture only. 
Table 1. Female directors and social enterprise revenue

\begin{tabular}{|c|c|c|}
\hline & Ln(revenues) & Ln(revenues) \\
\hline Female director & $\begin{array}{c}-0.360 \\
{[0.198]}\end{array}$ & $\begin{array}{l}0.3320 \\
{[0.427]}\end{array}$ \\
\hline Director's age & $\begin{array}{l}0.0092 \\
{[0.009]}\end{array}$ & $\begin{array}{c}0.008 \\
{[0.009]}\end{array}$ \\
\hline Director's education & $\begin{array}{c}0.273 \\
{[0.118]^{\star \star}}\end{array}$ & $\begin{array}{c}0.251 \\
{[0.119]^{\star \star}}\end{array}$ \\
\hline $\begin{array}{l}\text { Female director*Country }{ }^{\mathrm{a}} \\
\text { Woman * UK } \\
\text { Woman * HU }\end{array}$ & No & $\begin{array}{c}\text { Yes } \\
-1.07 \\
{[0.558]^{*}} \\
-1.174 \\
{[0.634]^{*}}\end{array}$ \\
\hline Organization's age & $\begin{array}{c}0.020 \\
{[0.005]^{\star \star \star}}\end{array}$ & $\begin{array}{c}0.029 \\
{[0.005]^{\star \star \star}}\end{array}$ \\
\hline NPO Type ${ }^{\text {b }}$ & Yes & Yes \\
\hline Country Fixed Effect & Yes & Yes \\
\hline $\mathrm{N}$ & 511 & 511 \\
\hline R2 & 0.32 & 0.33 \\
\hline
\end{tabular}

Notes: a baseline category is woman*ES, the other interaction terms not mentioned were not statistically significant. b Same results if we control for economic activity or operational model instead of NPO type.

Along similar vein, the share of self-generated revenues is on average lower amongst ventures run by women compared to those run by men - 53\% versus $64 \%$. However, once we control for observable characteristics of the venture itself (like the organization's age, social sector type or organizational model, size) and country fixed effects, gender no longer systematically predicts the venture's share of selfgenerated revenues. In other words, the overall average gender difference in share of self-generated revenues captures in fact the apparent gender differences in the type of ventures run.

\section{Management practices and Performance}

When asked about the three most important targets that their organization wishes to achieve in the coming 12 months, women are much less likely to mention targets linked to the formation/realization of agreements, collaborations or alliances $-29 \%$ of women versus $43 \%$ of men. This is consistent with evidence elsewhere showing a gender gap in the likelihood to initiate negotiations. Women seem less inclined to negotiate (Small, 2007), but only in the presence of a male evaluator (Bowles et al., 2007). Interestingly, the most frequently mentioned targets relate to revenues and social impact - this is true both for male and female social entrepreneurs. Both were mentioned by over half of all respondents.

Compared to male social entrepreneurs, and controlling for age, sector focus, operational model and country location of the social enterprise, female social entrepreneurs are significantly more likely to engage in participatory management practices (Table 2). This is consistent with the view that women are more relational, expressive and communal, whereas men are more autonomous, instrumental and agentic (Schwartz, 2010). This finding in turns raises the perhaps more urgent question whether this difference in management style also produces performance differences. Using SELUSI data, Stephan, Huysentruyt and 
Vujic (2011) find that participatory management practices are positively associated with social enterprises’ rates of innovation.

Table 2. Female directors and Participatory Management Practices

\begin{tabular}{|c|c|}
\hline & $\begin{array}{l}\text { Participatory Management } \\
\text { Practices }\end{array}$ \\
\hline Female director & $\begin{array}{c}0.188 \\
{[0.072]^{\star * *}}\end{array}$ \\
\hline $\ln \left(\right.$ revenues) ${ }^{a}$ & $\begin{array}{l}0.0001 \\
{[0.016]}\end{array}$ \\
\hline Director's education & $\begin{array}{c}0.083 \\
{[0.044]^{\star \star}}\end{array}$ \\
\hline Director's age & $\begin{array}{c}-0.002 \\
{[0.003]}\end{array}$ \\
\hline NPO Type ${ }^{\text {b }}$ & Yes \\
\hline Country Fixed Effect & Yes \\
\hline $\mathrm{N}$ & 511 \\
\hline R2 & 0.18 \\
\hline
\end{tabular}

Note: a Same results if we control for In(FTE) instead of In(revenues). b Same results if we control for economic activity or operational model instead of NPO type

Controlling for age, sector focus, operational model and country location of the social venture, no gender differences in revenue growth (in current revenues) or profit/surplus growth can be found. Interestingly, female-run social ventures rate their own organization's social impact relative to other organizations in their field consistently higher.

\section{Innovation}

\section{Incremental, Radical Innovation and New Market Creation}

One of the arguably most striking findings about social ventures is their seemingly high propensity to innovate. On average $88 \%$ of social ventures interviewed state they had introduced at least one new or significantly improved process, service and/or product in the past 12 months $(\mathrm{N}=546)$. And this is the case for both female and male run ventures alike: $87 \%$ and $89 \%$ of female-led and male-led social ventures (no statistical difference). More specifically, $62 \%$ of social ventures innovate their services, $60 \%$ their processes, and $27 \%$ their products - though often they introduce a combination of these. Again, this is true, regardless of whether the ventures are run by men or women.

What's more, the share of social enterprises that have introduced a radical innovation or innovation that is new-to-the market in the past 12 months is also very high: on average $60 \%$. This is effectively high, both in comparison with the share of radical innovators amidst traditional commercial enterprises and public sector agencies. Again, this proportion is statistically the same for both women-led (58\%) and menled social enterprises (62\%). As before, $67 \%$ of those radical innovations are also service-related.

When it comes to new market creation - entering/pioneering new markets, women seem to be taking the lead over male social entrepreneurs. More specifically, $62 \%$ of social ventures run by women were the first to provide this kind of service or product in their region, country or worldwide. This share is significantly lower for those ventures run by men (54\%). Interestingly, this discrepancy remains even after 
we control for observable venture type characteristics and allow for systematic differences along this dimension across countries.

Figure 5. Female social entrepreneurs and innovation

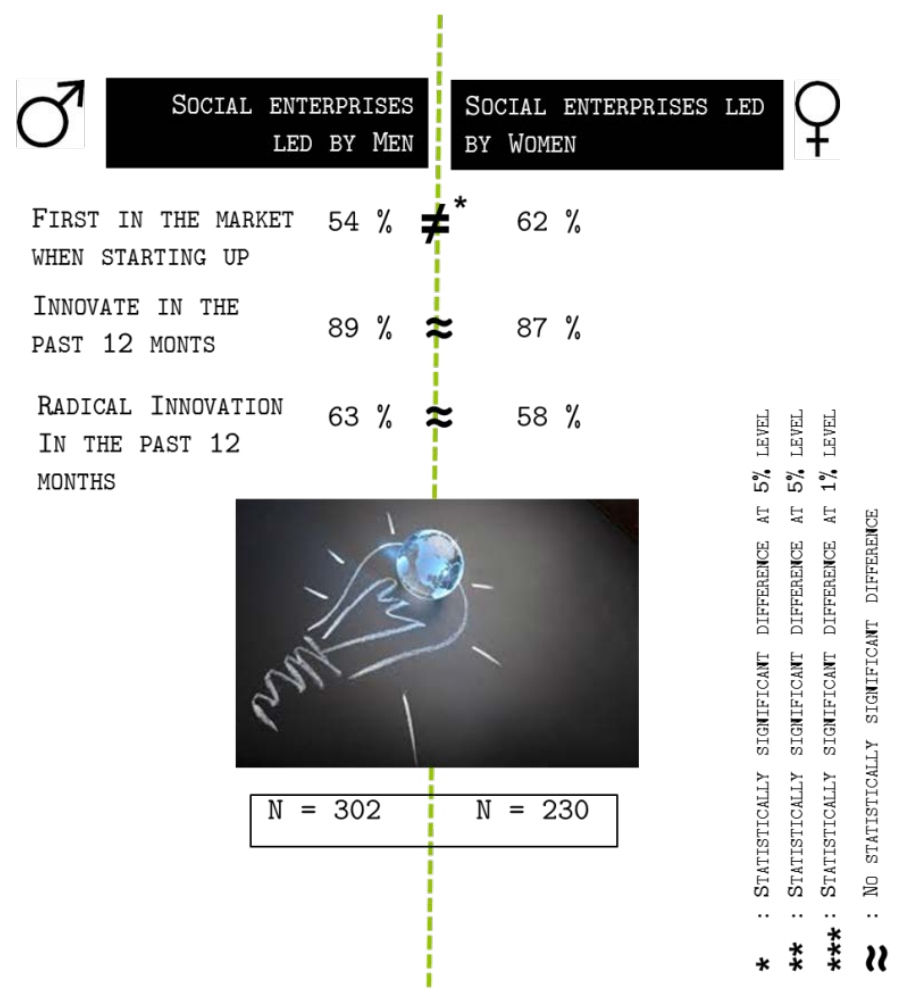

\section{Drivers and Barriers of Innovation}

Not surprisingly, virtually all social entrepreneurs find innovation important (98\%) - and again, this is true regardless of the entrepreneurs' gender. The most common driver for innovation is to increase social and environmental impacts (mentioned by $62 \%$ of all social entrepreneurs) - and both women and men were most likely to mention this. Along some of the other reasons why, we observe gender differences: The following reasons are mentioned more often by women: (i) to increase product range (48\% versus $41 \%$ ), and (ii) to respond to competitive pressures (24\% versus $18 \%$ ). We also find that overall women are more likely to point out regulatory pressures (10\% versus $6 \%)$. This latter gender difference is, however, driven by differences in institutions across country contexts. This was mainly mentioned in Hungary and Romania, where (recall) the share of female-run social ventures is greater than male run social ventures.

The share of social ventures that had experienced problems introducing an innovation in the past 12 months is on average $65 \%$ and roughly the same across female and male social entrepreneurs. The most common barriers to innovation mentioned were finance-related, though it should be noted that only $55 \%$ of those had experienced difficulty innovating also mentioned at least one specific reason. More broadly, the evidence suggests no gender differences in specific barriers to innovation (also when we hold constant country context).

Of course, interesting country differences in drivers and barriers to innovation seem to exist. For example, finance related drivers of innovation (like enhancing financial sustainability or expanding markets) were more frequently mentioned by Romanian social entrepreneurs (76\%) than those in other countries (overall average 43\%). Pressures from competition and financing agencies were significantly 
more often mentioned by Swedish social entrepreneurs (35\%) and less often by Spanish ones (4\%). Increasing social and environmental impacts was much more often mentioned by UK social entrepreneurs (78\%), whereas very few Romanian social ventures mentioned this (24\%). As for the barriers to innovation, costs were most often mentioned by Hungarian social entrepreneurs (53\%) and least common barrier expressed by Swedish social ventures (20\%),

\section{Innovation investments and outcomes}

Female run and male run social enterprises invest on average equal sums on product/service innovations. Concerning process innovations, by contrast, female entrepreneurs seem to expend significantly less money.

\section{Innovation and Collaboration}

Another striking finding is that social ventures behave very collaboratively when it comes to innovation - both in terms of having contributed to the development of another organization's innovation [over the past 12 months] (90\%), and having worked with others in developing new products, services and/or processes at their organizations [over the past 12 months] (78\%). This holds true again for both female- and male-run social ventures. By comparison, for-profit companies report less cooperation in their innovation processes. ${ }^{6}$

Overall, collaborations (in the development of an own innovation) occur most frequently with pure nonprofits (27\%), government bodies (24\%) and pure for-profits (17\%). But again, we observe no systematic gender differences in the type of organization they involve. But interesting country differences appear. For example, Swedish social enterprises are much less likely to collaborate with public sector agencies, and far more with for-profits.

\section{Box 3. Illustrations of innovations}

Product innovation: For instance, the launch of a new financial tool to help teach young people essential financial literacy skills; the launch of a new chutney produced using surplus of fruit and vegetables and produced by disadvantaged people; the launch of a new, smart metering widget designed to help reduce household energy consumption.

Service innovation: For instance, the launch of a new service that offers re-usable materials as a raw material to creative entrepreneurs; the introduction of fix your own bike training sessions (by a social enterprise whose mission is to actively change lives and provide positive experience using bicycle); the introduction of a showering service for homeless people.

Process innovation: For instance, the introduction of a new distribution system that relies on mothers selling to fellow mothers all across the country; the introduction of a participatory approach, involving youngsters who have fled their homes in the past, to design a communication strategy that can support youngsters who face similar problems at home; the introduction of a new logistical system when sourcing in agricultural products locally for redistribution to households.

$6 \quad$ Overall EU-27 benchmark is 25\% (Parvan, 2009) and for individual countries: Hungary 39\%, Romania 17\%, Spain 17\%, Sweden 40\%, UK 30\% (Parvan, 2009, all CIS 2006). 


\section{Three Cases}

We now draw on several specific experiences of three women social entrepreneurs to shed further light on the realities of women social enterprises with regards to innovation. In doing so, we allow for more contextual detail to help enrich (inspire) further understanding of the nature, meaning and role of innovation amidst female run social enterprises.

To select these cases, we proceeded fairly pragmatically. We chose to search for an case in Hungary, simply because of the very high prevalence of women in social entrepreneurship in this country. We chose a case in Russia simply because so little is known about social entrepreneurship in Russia and we anticipate a sharp growth of social enterprise in the near future. Not only new social enterprises but also new collaborations between civil society and local government are cropping up in an attempt to radically improve the quality of basic social service provision. We also plan to extend the SELUSI database to Russia, so for us, this was also a good opportunity to learn more about the context. Chile was selected, again, as we were looking for a case outside Europe. What is intriguing about Chile is the speed with which new social enterprises are emerging and the many measures government is taking to promote the phenomenon. In each of these countries, we also had good personal contacts with a large contact network of social enterprises, and whose advice we solicited when shortlisting the cases;

To select the actual cases, we approached experts on social enterprise in those countries to provide us with suggestions. For Hungary, we also applied the following criteria to our SELUSI database to help narrow our focus: (i) A woman is the director, (ii) She finds it important to innovate, (iii) The organization puts a strong emphasis on innovation (strategic orientation towards innovation) as captured by responses to 5 statements; (iv) The organization has introduced a service, process or product innovation in the last 12 months. Csimota -the Hungarian social enterprise that was recommended to us by practitioners had also made it onto our 'shortlist' we had created having applied these four criteria to the SELUSI database.

In each case description, we primarily draw on own material we gathered through a 1-hour semistructured phone interview. Two were conducted in English; whereas one was conducted in Russian. These short descriptions are far from in-depth case analyses: e.g., only one source was solicited - namely the voice of the woman/women leading the social enterprise. Their stories serve to 'bring people into the report, and add another (modest) layer of insights about women social entrepreneurship and innovation to the many statistics presented so far.

\section{Casa de la Paz: Interview with Ximena Abogabir ${ }^{7}$}

Casa de la Paz is an association based in Santiago (Chile) whose mission it is educate the public about the environment and articulate agreements between businesses, community and the government to promote sustainable coexistence with the environment in a socially just and economically viable manner. For their clients, who are primarily (foreign) companies, they design an integral/systemicapproach to engaging with the communities where they operate. They help to identify the client's stakeholders, bring them together, formalize an alliance, come up with a common agenda, keep focused on that agenda and ensure all the agreements get realized. "The bad news is this takes a lot of time... Companies that come to us often volunteer, and in this role, has been able to focus more on strategy. Prior to Casa de la Paz, she worked in the field of education and twelve years in advertising. In 1995, she was selected as Chile's first Ashoka Fellow. 
dream there is an aspirin..." The process is also complicated "[Clients] are not always willing to share power...Requires a revolution of aspirations ...”

Casa de la Paz grew out of a peace environmental activist movement in the eighties. At the time, everything was done on a voluntary basis and it was legally impossible to formalize an NGO. The association was founded in 1992, and it was in 1996 with the arrival of Shell that their work really took off. "[Shell] understood that we are not against private companies... it is about solving problems." Today, Casa de la Paz is a team of close to 40 individuals. They generate revenues of 2 Million USD, 70\% through their consultancy, the remaining 30\% through their environmental educational activities. The overwhelming majority of revenues (80\%) are self-generated through the sales of their services to the private sector. They occasionally bid for investigations or study projects (E.g., outsourced by the Chilean government (predominantly) and World Bank). They receive very few donations, which they feel is important to "maintain independence."

Change at Casa de la Paz is fast-paced. "The world is changing so much... Our achievement is our ability to adapt to change... Today, we work together with universities to validate our new social intervention model... We are trying to understand what we mean by that..."Our objective is to do things better and to share. What about competition? "Great, time to move on ... When private consultants are doing the same, it’s time to move on, pioneer something new.”

Since 1996, Casa de la Paz has had 6 Executive Directors... They have traditionally always been women. "I understand they each have their own agenda. I place myself behind them... I have learned to let go, let go of issues ... something new will come in ... as long as they stick to our mission and vision.

Abogabir understands the difficulty of being a woman but has never experienced this herself. .. "We [women] have the capability to get our point through with empathy ... to understand people's role and limitations, to build on that, not to destroy. Being a woman helps relate to people.” There have always been more women than men working at Casa de la Paz. This, Abogabir believes, has been an asset "helping them build true, sincere relationships with the community, where there is real trust, not pragmatic relationships.”

Innovation is important for Casa de la Paz: "it's a matter of survival," states Abogabir pragmatically. "Private companies can do things faster; they are much more intensive in human resources than companies." "We always ask ourselves questions... We reflect a lot over what we do. There is little copy/paste work in what we do," and so they seem to be obliged to innovate as a matter of course. Staff rotates a lot, and with new people and new knowledge come new ideas. Casa de la Paz does not have a very rigid structure. Staff is also very diverse - some people have been working at Casa de la Paz for 12 years; others are freshly minted graduates.

\section{Csimota: Interview with Suzanna Fodor ${ }^{8}$}

Csimota is a limited company based in Budapest that was started-up in 2003 by two women with the mission to publish and distribute innovative, progressive new-to-the market design and children's books. Made by young talented artists, their books offer a way for the aspiring artists to develop a network. By promoting topics of tolerance and acceptance, as well as distribution of such literary works throughout Hungary, they aim to raise social awareness more broadly. They also try to educate teachers and mothers about the importance of using fresh language and reading materials, and effectively helping them better

8 Suzanna Fodor joined Csimota in 2009, becoming the main co-owner next to Dora (who is also one of the founders). Before then, she worked in the hotel industry for two years, and started running a sign language course for babies, in which she invested for two years. 
engage with (their) children in the reading process at an early age. More recently (since 2009), they have broadened their scope to include book trading (not necessarily books of their own publishing house), and under the Rainbow label representing 30 other publishing houses.

It seems as if this move towards more diversification in turn has sparked more than one clever innovation. To illustrate, they have set up a direct retail network throughout the country that harnesses the energies of mothers - "After having a child many mothers in Hungary find themselves at home taking-up childcare, but after a while, feeling they are not a useful part of society. Some decide to start a study or play group, and at times very successfully so.” But many do not readily find ways to rejoin the labor market. It is those mothers in particular that Csimota aims to empower by engaging them like commissioned sales(wo)men for their books. In doing so, they at once drastically expand the reach of their retail market.

Another example of a recent innovation involves the design of correspondence game for kids. After a successful pilot-test, they are now looking to scale-up the game nationwide, and so reach over 500,000 kids. The game involves the back and forth correspondence of literary excerpts (from the books they publish), questions and answers marketing (four rounds in total).

Today Csimota is owned-managed by two women (one of them also a founder) - furthermore, a colleague was given $3 \%$ of shares to compensate for his work for which they weren'table to pay. However, this structure might well change considerably in the near future as negotiations are under well way with a potential new investor, an old traditional publishing house (10 times bigger than them). This candidate investor sees real value in what Csimota does and would offer professional logistical support, so that the Csimota team can focus more on the making and selling of their books.

When starting up, there were of course other organizations doing the same, publishing books. However, what set them apart is their eye for new, unknown talent (some of the artists they picked up have become well-known, publishing in The New Yorker), and their special interest/focus on books with a strong social message. Every year, they publish at least one book in this series of touching topics with any surpluses going to an NGO. Last year, for instance, they published a book about a girl with Down's Syndrome. "The biggest challenge is ensuring these books make it to the shelves ..."

In Fodor's view, "being small is advantageous." The big publishing houses are mostly run by men, with "a different style." They [men running the big publishing houses] are "not prepared to carry boxes." When asked about her/their management style, Fodor describes it is as "very efficient and democratic. If an issue arises, we discuss it." They also seem very versatile and intelligent ininvolvingrelevant outside expertise, for instance when negotiating the merger. Fodor is particularly proud about the good team/work relationships, complementary expertise and work routines, and notably the strong trust there exist between Dora and herself

As for the importance of innovation (like Casa de la Paz): "it's our survival." Yet challenges are mounting. With the economic crisis, "money spent on books and culture is the first thing families cut." Furthermore, "there is big uncertainty about what's going to happen... With the Florint being tied to the EURO, purchasing books is very expensive... A lot of books are printed in China ... but bringing-back buying rights are very expensive...”

When asked about whether they had experienced any difficulty introducing an innovation in the past 12 months, Fodor readily brings up the example of a musical book about Jazz that they were hoping to launch. They had already invested quite a bit of time and energy, yet the music team was in fact shopping around trying 5 different other publishing houses. 
But this disappointment is part of a "learning curve," and indeed the last thing you might suspect from Csimota is that they sit still discouraged, just hoping for better times. Quite the opposite, Csimota is aggressively exploring avenues to promote sales of their books abroad. Revenues in 2011 were 75,000 EUR, revenues in 2012 are projected to be 100,000 EUR. In fact, Fodor's intuitions are that "when the economy is not good and there is less and less help from state and corporates, people begin do something on their own, look for connections..." And it is this growing interest into the phenomenon of social enterprises which Csimota hopes to help accelerate ... and benefit from.

Merry Felt: Interview with Liyah Visnapu ${ }^{9}$

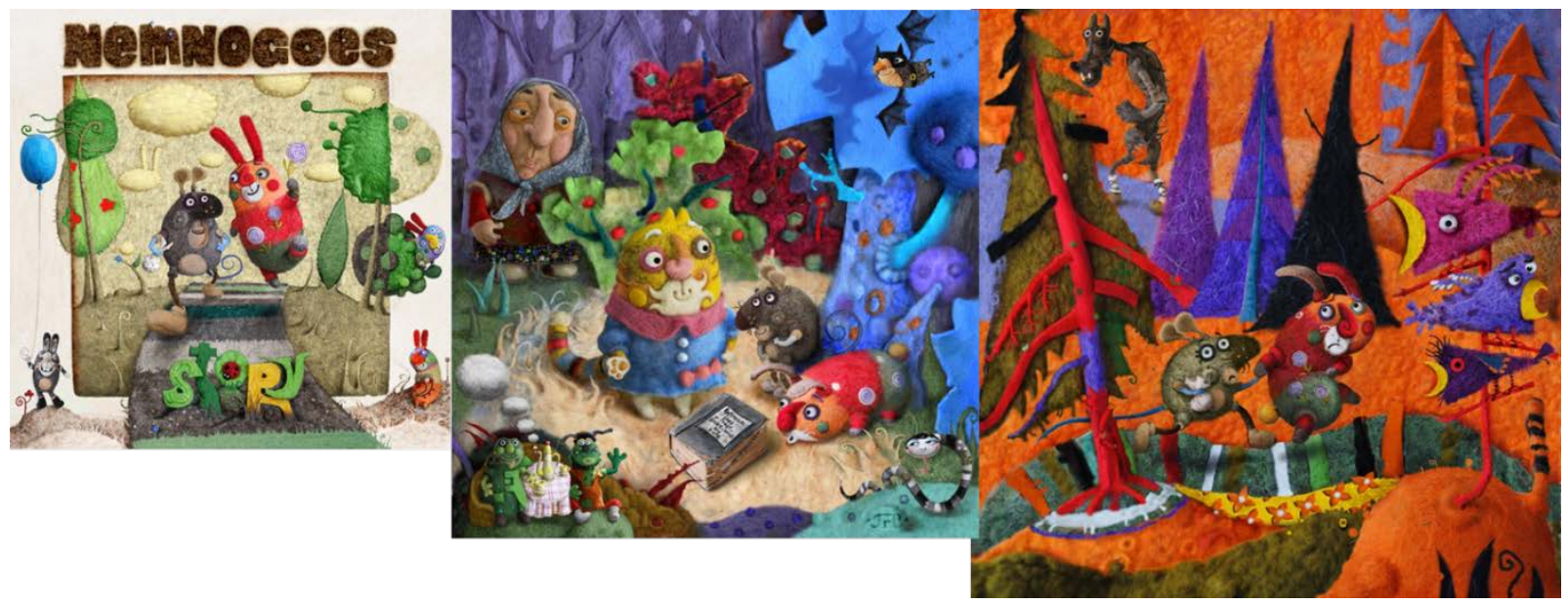

Merry Felt is a social enterprise based in Rybinsk, a medium-sized town in Russia, that teaches mothers how to make high quality design felt characters, get those women involved in the creative process and so find extra earnings. Merry Felt essentially helps mothers, who otherwise find it difficult to access jobs, re-engage with the labor market and in doing so feel empowered and learn new skills. But "we do more than that...we pay [our workers] on a weekly basis. This is unusual as "in many companies in Rybinsk, salaries are paid with some 6-month delay.” With a team of 15 workers, they produce about 300 felt characters each month.

The societal challenge Merry Felt aims to address is precisely what pushed Visnapu to start-up Merry Felt. As a mother of 5, wanting work that is creative, having had little previous experience working outside from home, and really needing to be at home, "I didn't have much of choice really." In 2008, together with her partner (a very talented designer), Visnapu received start-up funding support from "Our Future" -a Russian-based Fund of regional social programs established by Vagit Alekperov, President of one of the largest Russian oil and gas companies LUKOIL. With support from Oxfam GB in 2009, they further increased sales through promoting the felt characters at a number of all-Russia arts exhibitions held in Moscow.

According to Visnapu, the biggest challenges Merry Felt faces today are threefold: Firstly, demand for their goods is still very seasonal, with peaks in autumn and winter (with even corporate clients placing an order as a gift for their employees), but very little demand in spring. Secondly, it is difficult to bring together all the women working for Merry Felt. Many are busy or have to take care of their children; moreover the enterprise does not have dedicated workspace for these women. Thirdly, Russia as it is a very

$9 \quad$ Liyah Visnapu (together with her husband Pavel Gravikov) founded Merry Felt in 2009. Prior to that, she was living with her family in St Petersburg, used to get involved with a lot of projects with the Orthodox Church trying to help people. 
centralized country with the majority of things happening in Moscow. This means that Visnapu finds herself having to travel extensively, doing the 5-hour drive to Moscow...

Visnapu runs her venture in a very informal way. "It is important for me to have flexible agenda. Luckily women who work with us normally find us themselves and my role is rather coordinating them." She sums up her management style as follows: "I try to give the impression I do not manage it [Merry Felt]. This is in fact what makes her proud: I'm happy collaborating with people rather than managing them." Visnapu sees no difference to managing a company for women versus men, and states "I actually do not have more problems than men running a company."

Once again innovation is a "matter of survival." They feel obliged to continuously pilot-test new products, new product bundles and distribution channels and tactics. For example, in order to inspire sales and add maximum value to the felt figures, Merry Felt has sought to market their products as merchandising accompaniment to animal characters in stories. Through collaboration with Oxfam UK, sales of Merry Felt's products have also been tested in the UK.

It seems as if an original avenue for future growth involves growth through new partnerships. Yet, as a recent experience illustrates, this is no guaranteed success. Merry Felt has developed an agreement with a big factory that produces standard felt boots, a typically Russian product for cold Russian winters. "We agreed to produce unique pieces of colored felt that they would be able to add to the boots to make them trendy and original, and so for the factory to create a competitive edge. Unfortunately for us, they decided to double the price for those boots, while we offered a product for a fraction of their cost, which did not turn this project into a financial success.”

To the question "whether they are organized in a way that helps them stay innovative, Visnapu falls back on her core mission to create social value and the importance of integrity. "We remain ourselves... We keep on producing a top quality product with a good design at a reasonable price... With our design, we not only make the lives of those buying our products happier, but also those who are involved in the production."

\section{Discussion and Implications for Policy-making}

A few summary observations are in place -observations that notablyjuxtapose and pull together(i) the systematic patterns in female-run social ventures and innovation as revealed by large-scale, reliable data and (ii)the very specific realities of management and innovation as seen through the lens of three specific cases of female-run social ventures.

First, it is striking that the gender gap in social entrepreneurship is considerably smaller than the gender gap in mainstream entrepreneurship, and consistently so across the globe. At the same time, significant country-differences must also be noted. This finding is supported by both GEM and SELUSI data, and thus seems quite robust. We have drawn on the literature about the gender differences in prosocial value orientation, altruism, and attitudes towards competition to help explain these results.

The 'reduced gender gap'-finding suggests two compelling notions and one important warning: First, promotion of social entrepreneurship can act as a powerful lever towards promoting female entrepreneurship and female labor market participation more generally. Indeed, as the experiences of Casa de la Paz illustrate, women-run social enterprises seem to attract a fair share of women collaborators or colleagues. Second, women entrepreneurs, social and mainstream alike, seem capable of playing a key role leading us towards more societal change. This link between female entrepreneurship, in particular female social entrepreneurship on the one hand and transformative change that fosters more inclusive, green and smart growth, on the other has so far been widely underappreciated. As for the warning, it is important 
going forward that we monitor how the increased competitive pressures in the market of social enterprises will affect new entry and participation of women. This warning is suggested to us by the large, robust evidence that women tend to be more averse to competition than men and the observation that the competitive stance of social enterprises today indeed seems to be less aggressive compared to mainstream entrepreneurs. With increased competition in the markets of social entrepreneurs, there is the risk that women will opt or drop out, which would push up the gender divide.

Second, when we compare women-led social ventures and their male counterparts, it is remarkable how similar they are in size, profitability and growth, once we control for a host of observable firm-level characteristics. In the fields of social services and health, we do observe a relatively higher share of women compared to men, but when we compare women and men-led social enterprises in those fields, no general gender difference was found. Having said this, there seems to be some evidence of a gender difference in revenues in the UK and Hungary. Still, this is an important insight particularly since it casts doubts on the generalizability of the oft-heard, more popular assumption that women have a preference for "small ventures," they tend to think small, etc. The SELUSI data shows that overall women-led social ventures do not underperform compared to those led by men. The three cases likewise give evidence of the high ambitions of these female-run ventures.

Third, it is remarkable how innovative social enterprises in general are, and that this holds in fact equally true for male and female-run ventures. Compared to mainstream entrepreneurs (or public sector agencies for that matter), they are much more likely to introduce radical innovations. The three cases likewise underline the importance of innovation and lend support to the notion that social ventures seem to innovate as a matter of course. This is an important insight; again because it debunks the intuition that innovation is more of a 'masculine' affaire.

Fourth, despite the similarities between women-led and men-led social ventures in terms of innovation, there is one dimension where they seem to systematically differ. Women-led ventures seem to be more likely to open up new markets - that is, when starting up, providing a product/service which no one else at that time provided. This suggests that perhaps due their specific sensitivity towards social needs, women social entrepreneurs are notable 'lead innovators' when it comes to social innovation. Again, from a policy-making perspective, this is important as it suggests that the notion of women social enterprises having significant ripple effects - by creating new markets, they are arguably also crowding in new players who imitate them or follow their footsteps. From a diffusion of social innovations or longer term transition perspective, women may well be acting a distinct role (that warrants further scientific scrutiny).

Fifth, both the large-scale data and the case study evidence demonstrate that female social entrepreneurs seem more likely to adopt participatory management practices. This suggests the power of women social entrepreneurs to empower others (and in doing so, enabling colleagues to learn and develop important talents and skills). The real question though remains what influence participatory practices have on firm performance. Preliminary results (working paper) suggest that this management style is systematically associated with more innovation.

Finally, though these are five observations that consistently were born out of the evidence we've produced, it must be noted that there is still a big need for further research in this area! These observations hopefully invite more scientists, women and men alike, to step up to the challenge and find innovative ways to reliably capture the influence of gender on innovation and social venture growth, development and impacts. 


\section{REFERENCES}

Alvord, S., Brown, L., \& Letts, C. (2004), “Social entrepreneurship and Societal transformation: An exploratory study,” Journal of Applied Behavioural Science, 40: 260-282.

Austin, J., Stevenson, H., and Wei-Skillern, J. (2006), “Social and Commercial Entrepreneurship: Same, Different, or Both?,” Entrepreneurship Theory and Practice of Baylor University, 1-16.

Battilana, J., Leca, B., and Boxenbaum, E. (2009), "How Actors Change Institutions: Towards a Theory of Institutional Entrepreneurship,” The Academy of Management Annals: 65-107.

Bertrand, M. (2010), “New Perspectives on Gender” in Handbook of Labor Economics

Brandenburger, A.M. andNalebuff, B. (1996). Co-opetition: A Revolution Mindset That Combines Competition and Cooperation... The Game Theory Strategy That's Changing the Game of Business.

Chattopadhyay and Duflo, E. (2004),"Women as Policymakers: Evidence from a randomized experiment in India, Econometrica, 72(5): 1409-1443.

Christensen, C., Baumann, H., Ruggles, R., Sadtler, T. M. (2006), "Disruptive Innovation for Social Change," Harvard Business Review, December 84 (12)

Covin and Slevin (1989), “A conceptual model of entrepreneurship as firm behavior,” Entrepreneurship Theory and Practice,

Croson and Gneezy (2009), “Gender Differences in Preferences,” Journal of Economic Literature, 47: 448-474.

Dees, J.G. (1998), “The Meaning of Social Entrepreneurship,” Stanford University: Draft Report for the Kauffman Center for Entrepreneurial Leadership.

Defourny, J., Nyssens, M. (2010), "Conceptions of Social Enterprise and Social Entrepreneurship in Europe and the United States: Convergences and Divergences", Journal of Social Entrepreneurship, 1:32-53.

Eagly, A. H., Beall, A. E., and Sternberg, R. J. (2004), The psychology ofgender. New York: Guilford Press.

Eagly, A. H., Wood, W., andDiekman, A. B. (2000),"Social role theory ofsex differences and similarities: A current appraisal.” In T. Eckesand H. M.Taunter (Eds.), The developmental social psychology of gender, Mahwah, NJ: Erlbaum.

Estrin, S. and Micikiewcz, T. (2011), Institutions and Female Entrepreneurship, Small Business Economics, 37: 397-425.

Hechavarria, D., Ingram, A. Justo, R. Terjesen, S. (2012), "Economic, social and environmental value creation goals: discourse and practice by female and male entrepreneurs.” 
Geary, D. C. (1998), Male, female: The evolution of human sex differences.Washington, DC: American Psychological Association.

Huysentruyt, M., Stephan, U., Van Looy, B. (2011), “Corporate social opportunity recognition and the value(s) of social entrepreneurs.” SELUSI Working Paper.

Koenig, C. (2008), Business Owners’ Cultural Orientations: Conceptualization, Measurement, and Implications for Business Success in China and Germany. Retrieved from http://geb.unigiessen.de/geb/volltexte/2008/5504/pdf/KoenigChristine-2008-02-29.pdf.

Koenig, C., Steinmetz, H., Frese, M., Rauch, A., \& Wang, Z.-M. (2007), “Scenario-based scales measuring cultural orientations of business owners.” Journal of Evolutionary Economics, 17(2), 211-239.

Lumpkin, G. T. and Dess, G. G. (1996), "Clarifying the Entrepreneurial Orientation Construct and Linking It to Performance,” The Academy of Management Review, 21(1): 135-172.

Mair, J., Marti, I. (2006), "Social entrepreneurship research: A source of Explanation, Prediction, and delight,” Journal of World Business, 41(1): 36-44.

Nicholls, A. (ed). (2006), Social Entrepreneurship: New Models of Sustainable Change, Oxford: Oxford University Press.

Noya, A. (2006), What is social entrepreneurship,” presentation Emerging models of socialentrepreneurship:possible paths for social enterprisedevelopment in Central East and SouthEast Europe Conference, Zagreb.

Pinker, S. (2002).The blank slate: The modern denial of human nature.New York: Viking.

Porter, M. E. and Kramer, M. R. (2011), “The Big Idea: Creating Shared Value How to Reinvent Capitalism and Unleash a Wave of Innovation and Growth,” Harvard Business Review, January/February.

Schwartz, S. (2010), “Basic Human Values: Theory, Methods and Applications” http://segrdid2.fmag.unict.it/Allegati/convegno\%207-8-10-05/Schwartzpaper.pdf

Schwartz, S. and Rubel, T. (2005), "Sex Differences in Value Priorities: Cross-Cultural and Multimethod Studies,” Journal of Personality and Social Psychology, 89(6): 1010-1028.

Segram, (2010), Women social entrepreneurs driven by impact rather than size, Insead Knowledge.

Stephan, U., Huysentruyt, M. and Vujic. S. (2011), CEO Values, managerial practices and organizational performance: Evidence from European Social Enterprises. SELUSI Working Paper.

Terjesen, S. Lepoutre, J., Justo, R., Bosma, N. (2011), Global Entrepreneurship Monitor Report on Social Entrepreneurship.Global Entrepreneurship Research Association.

Themudo, N. S. (2009), "Gender and the Nonprofit sector,"Nonprofit and Voluntary Sector Quarterly, 38(4): 663-683. 


\section{SHORT EXPLANATION OF THE VARIABLES USED}

Participatory management practices. Although many measures of participation exist (typically from the perspective of employees), very few are suitable to capture the CEO's stance towards participation. We used a measure that has been directly validated using samples of business owners (Koenig, 2008; Koenig, Steinmetz, Frese, Rauch, \& Wang, 2007). It measure the extent to which the CEO encourages participation in decision making, giving employees a say, and equal distribution of decision power across the organization vs. pushes through decisions without regard to his/her employees and encourages unequal, hierarchical distribution of 'power'. It is a scenario-based measure consisting of five items that reflect decisions and typical behavior of the CEO regarding employee involvement vs. use of the CEO's position power to implement decisions without regard to employees. Example items are "Imagine that you have to make a decision that has important consequences for your organization. What do you do? You make the decision after having consulted your employees. vs. You make the decision without consulting your employees before.", "Imagine that one of your employees criticizes the way you run your organization.

Director's education. Categorical variable, recoded so that the higher the value, the higher the level of education completed.

Director's age. Age of the social entrepreneurs in 2010

Organization's age: Age of the social enterprise in 2010

ln(revenues). Natural logarithmic transformation of the social enterprise's total revenues in the past year

(Nov. 2008- Nov. 2009) - in EUR

$\ln$ (FTE). Natural logarithmic transformation of the total number of FTE employed by the social enterprise in first quarter 2010.

NPO Type. Categorical variable, relates to main activity only. Corresponds with the non-profit organization- classification.

Operational model. Categorical variable, relates to main activity only. Modified version of the typology of operational models made by Kim Alter (2007)

Economic activity type. Categorical variable, relates to main activity only. Corresponds with the NACE-code.

Country fixed effects: dummy variable for each country with Spain as baseline category. 